\title{
Peran Detasemen Gegana Satuan Brimob Polda Sumatera Utara dalam Penanggulangan Tindak Pidana Terorisme
}

\section{The Role Of The North Sumatera Brimob Undergency In Terroism Criminal Management}

\author{
Ghofur Hidayat*, Triono Eddy \& Alpi Sahari \\ Program Magister Ilmu Hukum, Universitas Muhammadiyah Sumatera Utara, Indonesia
}

Diterima: Juni 2020; Disetujui: Agustus 2020; Dipublish: Agustus 2020

*Email: hidayatghofur42@gmail.com

\begin{abstract}
Abstrak
Pemberantasan tindak pidana terorisme di Indonesia sangat gencar dilaksanakan disebabkan ancaman teror tersebut menimbulkan banyak korban jiwa serta keresahan masyarakat di lapisan masyarakat. Oleh sebab itu pemerintah mengeluarkan berbagai regulasi untuk mengatasi tidnak pidana terorisme tersebut. Pemberantasan tindak pidana terorisme tentu saja memerlukan sarana dan prasarana yang salah satunya adalah uni penjinak bom. Detasemen Gegana Satuan Brimob unit penjinak bom bertugas untuk menjinakkan bom yang biasanya digunakan oleh para teroris dalam melancarkan aksinya. Tulisan ini bertujuan untuk mengeanalisis atau mengkaji Peran Detasemen Gegana Satuan Brimob Polda Sumatera Utara dalam penanggulangan tindak pidana terorisme dan Hambatan yang dialami oleh Detasemen Brimob Polda Sumatera Utara dalam penanggulangan tindak pidana terorisme. Hasil dari dari penelitian ini menunjukkan bahwa peran Gegagana Korps Brimop Polri dilakukan dengan penjinakan bom yang dilakukan melalui tahap persiapan, pelaksanaan, dan konsolidasi. Hambatan yang dialami oleh Detasemen Gegana Satuan Brimop Polrda Sumatera Utara terdiri dari beberapa faktor internal dan eksternal.
\end{abstract}

Kata Kunci: Detasemen, Gegana, Tindak Pidana, Terorisme.

\begin{abstract}
The eradication of criminal acts of terrorism in Indonesia is very intensively carried out due to the threat of terror, causing many casualties and public unrest at the strata of society. Therefore the government issued various regulations to overcome the criminal acts of terrorism. The eradication of the crime of terrorism certainly requires facilities and infrastructure, one of which is the bomb disposal unit. Detachment of the Gegana Brimob Bomb disposal unit is tasked with defusing bombs which are usually used by terrorists in carrying out their actions. This paper aims to analyze or examine the role of the North Sumatra Regional Police Mobile Brigade Detachment in the handling of terrorism crimes and the obstacles experienced by the North Sumatra Police Mobile Brigade Detachment in dealing with terrorism crime. The results of this study indicate that the role of the Police Mobile Brigade Corps Gegagana is carried out by bomb disposal which is carried out through the stages of preparation, implementation, and consolidation. The barriers experienced by the North Sumatra Regional Police Mobile Brigade Detachment Unit consisted of several internal and external factors.
\end{abstract}

Keywords: Detachment, Gegana, Criminal Acts, Terrorism.

How to Cite: Hidayat, G., Eddy, T. \& Sahari, A. (2020). Peran Detasemen Gegana Satuan Brimob Polda Sumatera Utara Dalam Penanggulangan Tindak Pidana Terorisme. Journal of Education, Humaniora and Social Sciences (JEHSS). 3 (1): 44-51. 


\section{PENDAHULUAN}

Sejarah tentang terorisme berkembang sejak berabad lampau, ditandai dengan bentuk kejahatan murni berupa pembunuhan dan ancaman yang bertujuan untuk mencapai tujuan tertentu. Perkembangannya bermula dalam bentuk fanatisme aliran kepercayaan yang kemudian berubah menjadi pembunuhan, baik yang dilakukan secara perorangan maupun oleh suatu kelompok terhadap penguasa atau pemerintah. Sebelum Perang Dunia II, hampir semua tindakan terorisme terdiri atas pembunuhan politik terhadap pejabat pemerintah (assassination of government official) (Muladi, 2002)

Terorisme mulai ramai diberitakan oleh dunia internasional pada tahun 2001. Saat itu, terjadi teror yang menimpa Amerika Serikat berupa pembajakan pesawat terbang komersil yang ditabrakan ke gedung WTC (World Trade Center) di New York. Setelah serangan itu, otoritas setempat menyebut sebagai terorisme (Rahmat, 2017) Kejadian ini merupakan isu global yang mempengaruhi kebijakan politik seluruh negara-negara di dunia, sehingga menjadi titik tolak persepsi untuk memerangi terorisme (Mardenis, 2011) Kehadiran Pasukan Detasemen Gegana sebagai garda terdepan penjinak bom yang menjadi senjata ampuh para teroris dalam menjalankan aksinya. Pemakaian bom oleh teroris merupakan bagian yang tidak terpisahkan dari aksi terorisme karena memang tujuannya untuk menakut-nakuti masyarakat yang terkait dengan hilangnya nyawa. Oleh karena itu Detasemen Gegana Polri tentu saja harus memiliki prosedur yang ketat untuk menjinakkan bom sehingga masyarakat merasa aman.

Undang-Undang Nomor 15 Tahun 2003 tentang Penanggulangan Tindak Pidana Terorisme mengatur bahwa lembaga yang dianggap berwenang menangani terorisme adalah Polisi Negara Republik Indonesia. Tetapi karena terorisme juga tidak melulu membawa dampak korban sipil yang tidak berdosa saja, amat mungkin keamanan nasional juga menjadi taruhannya, banyak negara juga menyertakan militernya untuk berperan aktif dalam penanggulangan terorisme. Oleh karena itu, banyak negara yang mengantisipasi hal ini dengan membentuk satuan anti teror yang fleksibel yang berbasiskan kepolisian namun mempunyai kemampuan seperti dimiliki militer yang biasa disebut sebagai paramiliter. Awalnya terorisme dikategorikan sebagai kejahatan terhadap negara (Crime Against State) tapi lambat laun berkembang menjadi kejahatan terhadap kemanusiaan (Crime Against Humanity). Terorisme memiliki berbagai karakteristik, salah satu karakteristik terorisme adalah semangat radikalisme agama.

Di Sumatera Utara dari tahun 2000 sampai dengan tahun 2019 terjadi peledakan bom yang dilakukan oleh para teroris sebanyak 6 kali di beberapa lokasi di kota Medan. Detasemen Gegana Satuan Brimob telah hadir untuk melakukan tugas dan perannya sebagaimana aturan hukum yang berlaku. Perlu untuk melihat bagaimana Detasemen Gegana Satuan Brimob Sumatera Utara melakukan penegakan hukum terhadap aksi-aksi bom yang terjadi di Sumatera Utara. Berdasarkan latar belakang tersebut di atas, penulis tertartik untuk melakukan penelitian yang berjudul "Peran Detasemen Gegana Satuan Brimob Polda Sumatera Utara Dalam Penanggulangan Tindak Pidana Terorisme".

\section{METODE PENELITIAN}

Penelitian ini menggunakan penelitian hukum normatif, dengan pendekatan penelitian terhadap sistem hukum. Bentuk-bentuk penelitian hukum normatif sebagaimana yang dikatakan Ronny Hanitijo Soemitro meliputi: inventarisasi hukum positif, penelitian asas-asas hukum, penelitian hukum in concreto, penelitian sinkronisasi hukum, penelitian sistem hukum dan perbandingan hukum (Hanitijo, 1990). Dengan pendekatan konseptual dan bersifat deskriptif analisis. 


\section{HASIL DAN PEMBAHASAN \\ Pengaturan Hukum Tugas, Peran dan Fungsi Detasemen Gegana Satuan Brimob dalam Penanggulangan Terorisme}

Tindak pidana teroris pada umumnya dilakukan oleh elemen clandstine (jaringan bawah tanah) yang terorganisasi dan terlatih secara khusus. Tindakan pengamanan dilakukan kepada anggota tim sebelum melakukan aksi teror. Biasanya mereka dibuat sistem sel sebelum palaksanaan menghancurkan target. Pengintaian terhadap target sasaran teror dilakukan oleh personal yang bertugas secara khusus sebagai pengintai. Uraian di atas menunjukkan bahwa tindak pidana terorisme adalah musuh bersama yang dihadapi oleh bangsa Indonesia, terutama oleh aparat penegak hukum. Untuk menjamin penegakan hukum dapat dilaksanakan secara benar, adil, tidak ada kesewenang-wenangan, tidak ada penyalahgunaan kekuasaan, ada beberapa azas yang harus selalu tampil dalam setiap penegakan hukum, yaitu azas tidak berpihak (impartiality), azas kejujuran dalam memeriksa dan memutus (fairness), azas beracara benar (prosedural due process), azas menerapkan hokum secara benar yang menjamin dan melindungi hak-hak substantif pencari keadilan dan kepentingan sosial (lingkungan), azas jaminan bebas dari segala tekanan dan kekerasan dalam proses peradilan (Muladi, 2002).

Salah satu komponen aparat penegak hukum yang melaksanakan upaya penanggulangan kejahatan terorisme adalah Kepolisian. Tugas Kepolisian Negara Republik Indonesia sebagai alat negara adalah melaksanakan pengaturan, penjagaan, pengawalan, dan patroli terhadap kegiatan masyarakat dan pemerintah sesuai kebutuhan; menyelenggarakan segala kegiatan dalam menjamin keamanan, ketertiban, dan kelancaran lalu lintas di jalan dan membina masyarakat untuk meningkatkan partisipasi masyarakat, kesadaran hukum masyarakat dan ketaatan warga masyarakat terhadap hukum dan peraturan perundang-undangan, serta memelihara ketertiban dan menjamin keamanan umum (Pasal 14 Undang-Undang Nomor 2 Tahun 2002 tentang Kepolisian). Wewenang kepolisian dalam pelaksanaan tugas kepolisian tersebut adalah mengadakan tindakan menurut hukum yang bertanggung jawab dan dilaksanakan dengan syarat yaitu: tidak bertentangan dengan suatu aturan hukum; selaras dengan kewajiban hukum yang mengharuskan tindakan tersebut dilakukan; harus patut, masuk akal, dan termasuk dalam lingkungan jabatannya; pertimbangan yang layak berdasarkan keadaan yang memaksa dan menghormati Hak Asasi Manusia (Pasal 16 Undang-Undang Nomor 2 Tahun 2002 tentang Kepolisian).

Salah satu Korps Kepolisian yang memiliki peranan dalam penanggulangan tindak pidana terorisme adalah Korps Brigade Mobile (Brimob). Menurut Pasal 2 Surat Keputusan Kepala Polri (Skep Kapolri) No. Pol. KEP/53/X/2002 mengenai Brimob, dinyatakan bahwa Korps Brimob ditugaskan untuk menjaga keamanan, terutama yang berhubungan dengan penanganan ancaman dengan intensitas tinggi, dalam usahanya untuk mendukung keamanan dalam negeri. Anarki merupakan bentuk pelanggaran hukum yang membahayakan keamanan dan mengganggu ketertiban umum masyarakat sehingga perlau dilakukan penindakan secara tepat, dan tegas dengan tetap mengedepankan prinsip-prinsip Hak Asasi Manusia (HAM serta sesuai ketentuan perundang undangan yang berlaku). Peningkatan profesionalisme personel Brimob merupakan bagian dari peningkatan kinerja Korps Brimob Polri dalam menghadapi dan menanggulangi gangguan Kambtimas yang berintensitas tinggi serta tugas lain dalam lingkup tugas pokok Polri yang telah tertuang dalam Peraturan Presiden Nomor 5 Tahun 2017 Tentang Susunan Organisasi Dan Tata Kerja Kepolisian Negara Republik Indonesia pada tanggal 19 Januari 2017 sebagai perubahan atas Peraturan Presiden Nomor 52 Tahun 2010.

Perkembangan situasi keamanan akhir-akhir ini, baik dibidang politik, ekonomi dan sosial kemasyarakatan yang selalu bergerak cepat dan dinamis menjadi tantangan bagi Polri dalam mengemban tugas menjaga keamanan dan ketertiban dalam negeri. Terutama yang berkaitan dengan tugas kepolisian dalam menangani kejahatan berintensitas tinggi seperti terorisme, kejahatan menggunakan bahan peledak dan kelompok bersenjata. Polri sebagai penjaga Kamtibmas dituntut tampil terdepan dalam mengantisipasi dan menanggulangi segala gangguan keamanan. Terkait dengan hal itu, berdasarkan Peraturan Presiden Republik Indonesia Nomor 5 Tahun 2017 guna meningkatkan eksistensi dan peran aktif Polri dalam mendukung keamanan dan 
ketertiban masyarakat diperlukan penyempurnaan dengan melakukan restrukturisasi organisasi di lingkungan Polri, termasuk di dalamnya nomenklatur jabatan Kepala Korps Brigade Mobile (Kakorbrimob) dikukuhkan menjadi Komandan Korps Brimob (Dankorbrimob).

Adanya perubahan Nomenklatur dan Titelatur berdampak pada perubahan organisasi Korps Brimob itu sendiri. Seperti yang dikatakan Dankorbrimob pada saat pelantikan Komandan Pasukan Gegana dan Pelopor, bahwa Korps Brimob Polri merupakan satuan para militer yang pengorganisasiannya mirip dan serupa dengan militer. Dimulai dari ikatan satuan terkecil regu, peleton, kompi, batalyon, sampai resimen. Lebih lanjut disampaikan Dankor, perubahanperubahan tersebut perlu dibarengi dengan penyempurnaan struktur organisasi berupa restrukturisasi organisasi di lingkungan Korps Brimob dengan penambahan Pasukan Gegana dan Pasukan Pelopor Korbrimob Polri. Dalam perubahan Struktur Organisasi Tata Kerja (SOTK) di lingkungan Korps Brimob Polri terdapat penambahan jabatan dengan pangkat bintang satu yaitu Pasukan Pelopor dan Pasukan Gegana sebagai upaya untuk menjaga dan meningkatkan stabilitas keamanan dan ketertiban masyarakat terutama dalam menghadapi potensi gangguan keamanan yang berimplikasi kontijensi.

Korbrimob bertugas menyelenggarakan fungsi pembinaan keamanan khususnya yang berkenaan dengan penanganan gangguan keamanan yang berintensitas tinggi, dalam rangka penegakan keamanan dalam negeri. Korps ini dipimpin oleh seorang Inspektur Jenderal (Irjen). Peranan Brimob di dalam Polri adalah sebagai berikut: Peran untuk membantu fungsi polisi lainnya, Peran untuk melengkapi operasi kepolisian kewilayahan yang dilakukan bersamaan dengan fungsi polisi lainnya, Peran untuk Melindungi anggota unit Polisi lainnya serta warga sipil yang berada di bawah ancaman, Peranan untuk memperkuat fungsi kepolisian lainnya dalam pelaksanaan tugas operasional daerah, Melayani untuk menggantikan dan menangani tugas-tugas Kepolisian kewilayahan apabila situasi atau sasaran sudah mengarah ke kejahatan berkadar tinggi.

Salah satu unsur pelaksana utama yang berada di bawah Dankorbrimob Polri adalah Pasukan Gegana. Terbentuknya Gegana berawal dari pemikiran tokoh polri pada tahun 1974. Timbulnya pemikiran tersebut, didasari adanya issu terror terhadap Polda Metro Jaya sehingga untuk mengantisipinya dibentuk kompi satuan Gegana Brimob Polri yang pimpin Mayor Pol. Drs. Soemardi. Satuan Gegana terbentuk pada tanggal 27 november 1974 berdasarkan Skep Kapolda Metro Jaya no.Pol.Skep/29/XI/1974 tentang pembentukan kesatuan Gegana Komdak Metro Jaya, berdirinya Gegana merupakan realisasi fisik dan instruksi Menhantam Pangab Nomor: SHK/633/V/1972 tentang Penanggulangan Kejahatan Pembajakan Udara atau Laut dan Tetorisme Internasional. Meskipun satuan Gegana sudah terbentuk sejak tahun 1974 namun pengakuan dari departemen pertahanan keamanan baru ada pada tahun 1976. Keberadaan pasukan Gegana sebagai komponen pasukan elit di lingkungan Polri terus membenahi diri. ketika Jendral Polisi Drs. Anton Soedjarwo menjadi Kapolri, Gegana kemudian dikembangkan dari sebuah Satuan Kompi menjadi Detasemen sekaligus pemindahan kedudukan Mako dari Polda Metro Jaya ke daerah Pertamburan.

Pemindahan Markas Komando terjadi pada masa pimpian Letkol Pol. Drs. Soepeno dan selanjutnya pindah ke Mabes Polri Jakarta Selatan. Pada tahun 1985 terjadi peralihan kedudukan, Detasemen Gegana Metro Jaya ke Momapta Polri atau sekarang yang dikenal Korps Brimob Polri. Peralihan tersebut, berdasarkan Skep Kapolri No.Pol: Skep/104/III/1985. Kemudian Gegana pada masa pimpinan Letkol Pol. Drs. S.Y. Wenas, pada tahun 1988 Markas Komando Gegana dipindah ke kelapa dua. Sejak dibentuk hingga saat ini. Pasukan Gegana Korps Brimob Polri cukup membanggakan. Berbagai terror yang terjadi di Indonesia baik menggunakan senjata api. Bom maupun bahan kimia lainnya dapat ditangani dengan baik. Personel Gegana yang dilengkapi dengan kemampuan dan peralatan yang mumpuni dapat menganalisa setiap perkembangan jenis terror terutama yang menggunakan bahan peledak. untuk itu. Personel Gegana dituntut terus meningkatkan kemampuannya, karena perkembangan ancaman kejahatan seiring dengan pesatnya perkembangan ilmu dan teknologi menjadi tantangan dan tugas berat pasukan Gegana.

Pasukan Gegana Korbrimob merupakan unsur pelaksana utama yang berada di bawah Dankorbrimob Polri. Danpas Gegana bertugas Membina, Mengawasi dan Mengendalikan Satuan- 
satuan dalam lingkungan pasukan Gegana. Meningkatkan kemampuan personel dan mengerahkan kekuatan satuan atas perintah Dankorbrimob Polri. Dalam pelaksanakan tugasnya, pasukan Gegana menyelenggarakan fungsi sebagai 1). Pelaksanaan Manajemen Perencanaan, Operasional, SDM, Logistik, Provos, TIK, Kesjas, Yanma, Keuangan dan Tata Administrasi Urusan dalam lingkungan pasgegana. 2). Penindak gangguan Kamtibmas berkadar dan berintensitas tinggi khususnya kejahatan terorganisir yang menggunakan senjata api, bom, bahan kimia, biologi, radio aktif dan perlawanan terror. 3). Pemberian bantuan teknis fungsi Gegana pada kegiatan yang berskala nasional maupun internasional. 4). Pembina fungsi Gegana pada satuan Brimob Polda. Dalam struktur organisasi komandan pasukan Gegana dibantu seksi Perencanaan, Operasional, SDM, Logistik, Provos, TIK, Yanma, Urkeu dan Seksi Taud. Pasukan Gegana Korbrimob Polri terdiri dari tiga satuan yang masing-masing terdapat tiga Detasemen kecuali satuan Bantek yang memiliki dua Desasemen. Satuan pasukan Gegana adalah satuan Perlawanan Terror (wanteror) bertugas sebagai penindak gangguan Kamtibmas berkadar dan berintesitas tinggi khususnya kejahatan terorganisir yang menggunakan senjata api dan atau perlawanan teror serta pembebasan sandera.

Tugas dan fungsi utama dijelaskan lebih lanjut pada Pasal 18 Ayat (2) yang berkaitan dengan Unsur Pelaksana Utama, dan lebih spesifik yakni pada satuan Gegana dan Pelopor. Gegana, berdasarkan perintah dari Komandan Brimob, dapat bertindak dalam menghadapi pelanggaran keamanan berat, terutama kejahatan terorganisir yang menggunakan senjata api dan bahan peledak ataupun yang melakukan serangan teror berskala nasional ataupun internasional. Secara lebih spesifik satuan yang secara khusus bertugas mengantisipasi ancaman terorisme adalah Unit Penjinak Bom (Subden 2 Jibom) yang berada di bawah Detasemen Gegana Satuan Brimob. Sesuai dengan namanyasatuan ini bertugas melakukan penjinakan terhadap ancaman bom yang biasanyadigunakan teroris untuk menebarkan teror dan menakut-nakuti masyarakat.

Satuan Jibom bertugas sebagai penindak gangguan Kamtibmas bekadar dan berintensitas tinggi khususnya kejahatan terorganisir yang menggunakan senjata api dan atau bom. Satuan KBR bertugas sebagai penindak gangguan kamtibmas berkadar dan berintensitas tinggi khususnya kejahatan terorganisir yang menggunakan bahan Kimia. Biologi dan Radioktif. Dan Satuan Bantek yang terdiri dari detasemen bantuan taktik dan desemen pengembangan bertugas sebagai bantuan teknis fungsi Gegana dalam penindakan gangguan Kamtibmas berkadar dan berintensitas tinggi. Satuan Bantek terdiri dari dua detasemen, yaitu: pasukan Gegana kedepan akan menghadapi berbagai perkembangan gangguan kamtibmas berintenrasitas dan berkadar tinggi yang semakin kompleks dan mengarah pada Transnational Crime (Terrorism, Kimia And Bioterrorism, Narcoterorism, Cyber Crime), perkembangan ilmu pengetahuan dan teknologi. khususnya teknologi informasi dan komunikasi yang terjadi di eksternal dan internal polri berpengaruh terhadap kondisi kamtibmas yang berdampak pada operasionalisasi tugas pokok dan fungsi pasukan Gegana karena belum didukung dengan peralatan terkini (Nasution, 2017).

Hambatan lainnya, sesuai perkap Nomor 06 Tahun 2017 Tentang Satuan Organisasi pada tingkat Mabes Polri daftar susunan personel (DSP) berjumlah 3.312 namun jumlah riil personel pasukan Gegana saat ini baru sejumlah 983 orang terdiri dari 966 orang anggota Polri dan 17 orang PNS sehingga masih terdapat kekurangan personel untuk mendukung operasional maupun fungsi staf pas Gegana dan jajaran. selain itu, berbagai kendala juga dialami pasukan Gegana seperti terbatasnya sarana dan prasarana serta peralatan yang digunakan untuk mendukung tugas-tugas pasukan Gegana. Dan yang perlu mendapatkan perhatian lebih terdahap keselamatan personel setiap melaksanakan tugas yang berisiko tinggi adalah belum adanya tunjangan resiko keselamatan kerja atau asuransi jiwa. Tuntutan profesionalisme anggota belum didukung dengan tersertifikasi kemampuan dari Lembaga Sertifikasi Polri (LSP) sehingga tidak adanya legalitas secara tertulis mengakibatkan tidak diakuinya kemampuan tersebut untuk mendapatkan tunjangan fungsional juga menjadi hambatan yang perlu diperhatikan. Meskipun demikian dengan adanya hambatan dan permasalahan yang dihadapi saat ini tidak menyurutkan semangat personel pasukan Gegana karena dalam pelaksanakan tugas sehari-hari berpendoman pada moto pengabdian, yaitu "Pengabdian yang paling membahagiakan dalam hidup ini ialah apabila kita berbuat sesuatu bagi bangsa dan Negara yang menurut orang lain tidak mungkin mampu kita lakukan" dan motto operasional "Setia Tabah Waspada". 
Tujuan pencegahan ancaman tindak pidana terorisme oleh Gegana Satuan Brimob pada dasarnya adalah mencapai tujuan Polri, sebagaimana diatur dalam Pasal 1 Ayat (5) UndangUndang Nomor 2 Tahun 2002 tentang Kepolisian Negara Republik Indonesia, keamanan dan ketertiban masyarakat adalah suatu kondisi dinamis masyarakat sebagai salah satu prasyarat terselenggaranya proses pembangunan nasional dalam rangka tercapainya tujuan nasional yang ditandai oleh terjaminnya keamanan, ketertiban, dan tegaknya hukum, serta terbinanya ketenteraman, yang mengandung kemampuan membina serta mengembangkan potensi dan kekuatan masyarakat dalam menangkal, mencegah, dan menanggulangi segala bentuk pelanggaran hukum dan bentuk-bentuk gangguan lain yang dapat meresahkan masyarakat. Penjinak bom yang di singkat Jibom adalah salah satu kemampuan yang dimiliki oleh Satuan Brimob di seluruh indonesia.disebut unit karena setiap pergerakan jibom adalah satu unit yang terdiri dari 10 personil dan dipimpin oleh Kepala unit, dari 10 personil tersebut mempunyai tugas dan tanggung jawab yang berbeda (maaf disini kami tidak menyampaikan tugas dan tanggung jawab personil untuk menjaga privasi).

Penanggulangan tindak pidana terorisme oleh Gegana Korps Brimob Polri sesuai dengan pengorganisasian Polri dirancang bersifat sentralistik setelah diberlakukannya UU Nomor 2 Tahun 2002, hal ini dimaksudkan agar koordinasi antara kesatuan atas dengan kesatuan bawah berlangsung efektif, karena ada kesatuan yang dapat menjebatani antar dua kesatuan. Namun hal ini juga tidak lepas dari kelemahan, yaitu timbul birokrasi yang panjang dan berbelit-belit dalam alur administrasi, kurang responsive terhadap tuntutan warga masyarakat lokal, rentan akan politisasi penguasa nasional sehingga lembaga kepolisian kurang berperan untuk kepentingan rakyat, dan kurang fleksibel menghadapi perubahan di masyarakat (Abdussalam, 2009).

Masyarakat bagi Polri, bukan hanya kepada siapa mereka memberikan pelayanan (jasa kepolisian), tetapi juga kepada siapa mereka harus bertanggungjawab. Pertanggungjawaban hukum khususnya atas penggunaan kekuatan paksa fisik oleh individu-individu polisi maupun pertanggungjawaban organik kepolisian tentunya tidak meniadakan pertanggungjawaban publik (public accountability). Akuntabilitas publik kepolisian sangat penting mengingat pekerjaan polisi syarat dengan kewenangan diskresi dan upaya memaksa, bahkan menyangkut nyawa seseorang yang hal itu cukup sulit untuk dikontrol (lowvisibility) (Rahardi, 2012).

\section{Hambatan dan Kendala yang Dialami oleh Detasemen Gegana Satuan Brimob Polda Sumatera Utara dalam Penanggulangan Tindak Pidana Terorisme}

Tindak pidana terorisme yang selama ini terjadi di Indonesia digolongkan sebagai kejahatan serius dan/atau kejahatan luar biasa terhadap kemanusiaan, keamanan negara, dan kedaulatan negara serta terhadap berbagai aspek kehidupan bermasyarakat, berbangsa, dan bernegara sehingga penanggulangan tindak pidana terorisme perlu dilakukan secara berkesinambungan, terarah, dan terpadu, yang meliputi aspek pencegahan dan pemberantasan guna memelihara kehidupan yang aman, damai, dan sejahtera berdasarkan Pancasila dan Undang-Undang Dasar Negara Republik Indonesia Tahun 1945 (UUD NRI Tahun 1945). Dengan adanya rangkaian peristiwa yang melibatkan warga negara Indonesia bergabung dengan organisasi tertentu yang radikal dan telah ditetapkan sebagai organisasi atau kelompok terorisme, atau organisasi lain yang bermaksud melakukan permufakatan jahat yang mengarah pada tindak pidana terorisme, baik di dalam maupun di luar negeri, telah menimbulkan ketakutan masyarakat dan berdampak pada kehidupan politik, ekonomi, sosial budaya, keamanan dan ketertiban masyarakat, serta hubungan internasional. Organisasi tertentu yang radikal dan mengarah pada tindak pidana terorisme tersebut merupakan kejahatan lintas negara, terorganisasi, dan mempunyai jaringan luas yang secara nyata telah menimbulkan terjadinya tindak pidana terorisme yang bersifat masif yang apabila tidak segera diatasi mengancam perdamaian dan keamanan, baik nasional maupun internasional.

Tindak pidana terorisme diatur dalam Undang-Undang Nomor 15 Tahun 2003 tentang Penetapan Peraturan Pemerintah Pengganti Undang-Undang Nomor 1 Tahun 2002 tentang Pemberantasan Tindak Pidana Terorisme Menjadi Undang-Undang (UU Terorisme). UU Terorisme pada saat itu dibentuk karena adanya keperluan yang sangat mendesak yaitu rangkaian peristiwa 
pemboman yang terjadi di wilayah Negara Republik Indonesia seperti bom Bali I dan bom Marriott, Tahun 2003 telah menimbulkan rasa takut masyarakat secara luas, mengakibatkan hilangnya nyawa serta kerugian harta benda, sehingga menimbulkan pengaruh yang tidak menguntungkan pada kehidupan sosial, ekonomi, politik, dan hubungan Indonesia dengan dunia internasional. Peledakan bom tersebut merupakan salah satu modus pelaku terorisme yang telah menjadi fenomena umum di beberapa Negara.

Salah satu komponen aparat penegak hukum yang melaksanakan upaya penanggulangan kejahatan terorisme adalah Kepolisian. Tugas Kepolisian Negara Republik Indonesia sebagai alat negara adalah melaksanakan pengaturan, penjagaan, pengawalan, dan patroli terhadap kegiatan masyarakat dan pemerintah sesuai kebutuhan; menyelenggarakan segala kegiatan dalam menjamin keamanan, ketertiban, dan kelancaran lalu lintas di jalan dan membina masyarakat untuk meningkatkan partisipasi masyarakat, kesadaran hukum masyarakat dan ketaatan warga masyarakat terhadap hukum dan peraturan perundang-undangan, serta memelihara ketertiban dan menjamin keamanan umum (Pasal 14 Undang-Undang Nomor 2 Tahun 2002 tentang Kepolisian). Wewenang kepolisian dalam pelaksanaan tugas kepolisian tersebut adalah mengadakan tindakan menurut hukum yang bertanggung jawab dan dilaksanakan dengan syarat yaitu: tidak bertentangan dengan suatu aturan hukum; selaras dengan kewajiban hukum yang mengharuskan tindakan tersebut dilakukan; harus patut, masuk akal, dan termasuk dalam lingkungan jabatannya; pertimbangan yang layak berdasarkan keadaan yang memaksa dan menghormati Hak Asasi Manusia (Pasal 16 Undang-Undang Nomor 2 Tahun 2002 tentang Kepolisian).

Salah satu Korps Kepolisian yang memiliki peranan dalam penanggulangan tindak pidana terorisme adalah Korps Brigade Mobile (Brimob). Menurut Pasal 2 Surat Keputusan Kepala Polri (Skep Kapolri) No. Pol. KEP/53/X/2002 mengenai Brimob, dinyatakan bahwa Korps Brimob ditugaskan untuk menjaga keamanan, terutama yang berhubungan dengan penanganan ancaman dengan intensitas tinggi, dalam usahanya untuk mendukung keamanan dalam negeri. Anarki merupakan bentuk pelanggaran hukum yang membahayakan keamanan dan mengganggu ketertiban umum masyarakat sehingga perlau dilakukan penindakan secara tepat, dan tegas dengan tetap mengedepankan prinsip-prinsip Hak Asasi Manusia (HAM serta sesuai ketentuan perundang undangan yang berlaku. Tugas dan fungsi utama dijelaskan lebih lanjut pada Pasal 18 Ayat (2) yang berkaitan dengan Unsur Pelaksana Utama, dan lebih spesifik yakni pada satuan Gegana dan Pelopor. Gegana, berdasarkan perintah dari Komandan Brimob, dapat bertindak dalam menghadapi pelanggaran keamanan berat, terutama kejahatan terorganisir yang menggunakan senjata api dan bahan peledak ataupun yang melakukan serangan teror berskala nasional ataupun internasional. Pasal 19 Ayat (2) mengenai pelopor yang berdasarkan perintah dari Komandan Brimob, bertanggung jawab untuk pengendalian ketertiban publik dan perlawanan insurgensi, dalam mendukung keamanan dalam negeri. Brimob menjadi kekuatan polisi yang utama dalam operasi-operasi melawan gerakan separatisme bersenjata, kekerasan etnik dan agama, dan situasi konflik lainnya.

Secara lebih spesifik satuan yang secara khusus bertugas mengantisipasi ancamanterorisme adalah Unit Penjinak Bom (Subden 2 Jibom) yang berada di bawahDetasemen Gegana Satuan Brimob Polda Sumatera Utara. Sesuai dengan namanyasatuan ini bertugas melakukan penjinakan terhadap ancaman bom yang biasanyadigunakan teroris untuk menebarkan teror dan menakutnakuti masyarakat. Unit Penjinak Bom yang berada di bawah Detasemen Gegana Satuan Brimob Polda Sumatera Utara dalam menjalankan tugasnya tentu saja memiliki berbagai hambatan dan kendala yang sifatnya internal maupun eksternal, sehingga dapat menganggu jalannya tugas tersebut. Hambatan dalam penanggulangan ancaman bom oleh Detasemen Gegana Satuan Brimob Polda Sumatera Utara dalam pelayanan kepada masyarakat menurut konsep pelayanan prima menurut keterangan informan yaitu konsep A6 dengan menyelaraskan faktor-faktor sebagai berikut: Kemampuan (ability), Sikap (attitude), Penampilan (Appearance), Perhatian (Attention), Tindakan (Action), Tanggungjawab (Accountability), (Sarko, 2020). 


\section{SIMPULAN}

Aspek hukum penanggulangan teror bom yang dilakukan oleh Detasemen Gegana Satuan Brimob diatur dalam Pasal 1 ayat (5) Undang-Undang Nomor 2 Tahun 2002 tentang Kepolisian Negara Republik Indonesia, bahwa Standar Operasional Prosedur penanggulangan tindak pidana terorisme oleh Gegana Korps Brimob Polri diatur dalam Peraturan Kepala Kepolisian Negara Republik Indonesia Nomor 11 Tahun 2010 tentang Penanganan Penjnakan Bom. Peran Gegana Korps Brimob Polri dalam penanggulangan tindak pidana terorisme dilaksanakan dengan penjinakan bom yang dilakukan melalui tahap persiapan, pelaksanaan dan konsolidasi. Bahwa hambatan dan kendala yang dialami oleh Detasemen Gegana Satuan Brimob Polda Sumatera Utara terdiri dari factor internal dan eksternal. Solusi terhadap hambatan dan kendala tersebut antara lain adalah melakukan pendidikan atau semacam pelatihan agar kemampuan anggota Detasemen Gegana Satuan Brimob Polda Sumatera Utara semakin meningkat; Memberikan semacam pembelajaran dari segi attitude dan etika, agar perilaku dan perangai yang harus ditonjolkan ketika menghadapi masyarakat.

\section{DAFTAR PUSTAKA}

Abdussalam, H.R. (2009), Hukum Kepolisian Sebagai Hukum Positif dalam Disiplin Hukum, Jakarta: Restu Agung.

Mardenis, (2011), Pemberantasan Terorisme, Politik Internasional dan Politik Hukum Nasional Indonesia, Jakarta: Rajawali Pers.

Muladi, (2002). "Hakikat Terorisme dan Prinsip Pengaturan dalam Kriminalisasi", dalam Jurnal Kriminologi Indonesia, Volume 2, Nomor III, Desember 2002.

Muladi, (2002). Penanggulangan Terorisme Sebagai Tindak Pidana Khusus, Jakarta, Bahan Seminar Pengamanan Terorisme sebagai Tindak Pidana Khusus.

Nasution, A. (2017). Terorisme Di Abad Ke -21 Upaya Penegakan Hukum Terhadap Tindak Kejahatan Terorisme Dalam Perpektif Hukum Internasional Dan Hak Asasi Manusia.JURNAL MERCATORIA, 8(1), 54-74. doi:https://doi.org/10.31289/mercatoria.v8i1.647

Rahardi, P. (2012), Hukum Kepolisian, Kemandirian, Profesionalisme dan Reformasi Polri, Surabaya: Laksbang Grafika.

Rahmat, M. (2017). "Politik Hukum Terhadap Tindak Pidana Terorisme Dalam Pembaharuan Hukum Pidana Indonesia"., dalam Jurnal Wawasan Yuridika, Volume 1, Nomor 2, September 2017.

Soemitro, R.H. (1990), Metode Penelitian Hukum dan Jurimetri, Jakarta: Ghalia Indonesia. 